\title{
Synthesis, Structure Elucidation and Cytotoxicity of (+)-Usnic Acid Derivatives on U87MG Glioblastoma Cells
}

Huong Giang Thi Nguyen', Ngoc Vinh Nguyen', Van Anh Vo ${ }^{3}$, Wanjoo Chun ${ }^{3}$, Fadhil S Kamounah ${ }^{2}$, Ole Vang ${ }^{2}$ and Poul Erik Hansen ${ }^{*}$

${ }^{1}$ Institute of Drug Quality Control, 200 Co BAC Street, Ho Chi Minh city, Vietnam

${ }^{2}$ Department of Science and Environment, Roskilde University, DK-4000 Roskilde, Denmark

${ }^{3}$ Department of Pharmacology, School of Medicine, Kangwon National University, Chuncheon, Kangwon, South Korea

\begin{abstract}
A series of new usnic acid ketamine compounds [1-8] and their oxime analogues [9-12] were synthesized by reacting (+)-usnic acid with various amines and subsequent treatment with hydroxylamine hydrochloride. They were evaluated on the human glioblastoma-astrocytoma cell line (U87MG) by a MTT assay for cell viability in vitro. The ketamine-derivatives (Schiff bases) show significant cytotoxicity on U87MG cells. A novel $\mathrm{N}$-heterocyclic derivative (1,4-diazepine) showed an interesting tautomeric structure and displayed more activity on cancer cell line than (+)-usnic acid itself.
\end{abstract}

Keywords: Usnic acid derivative; DFT calculations; Glioblastoma cells; Cell viability

\section{Introduction}

Usnic acid (2,6-diacetyl-7,9-dihydroxy-8,9b-dimethyl$1,3(2 \mathrm{H}, 9 \mathrm{bH})$-dibenzofurandione; $\mathrm{C}_{18} \mathrm{H}_{16} \mathrm{O}_{7}$ ) (Scheme 1) is a lichen metabolite and both the $\mathrm{R}(+)$ and $\mathrm{S}(-)$ isomers can be found in nature. (+)-Usnic acid and its derivative exhibit a wide range of biological activities [1] such as antibiotic [2], antiviral [3], apoptotic [4,5], analgesic [6], antipyretic [6] and anti-proliferative [7] activities. The toxicity in vitro and in vivo has been evaluated by Guo et al. [8] and hepatotoxicity but no general toxicity was observed. Antitumor activity of usnic acid was displayed for the first time by Kupchan and Kopperman [9] against Lewis lung carcinoma in mice. In addition, cytotoxicity activity of usnic acid and usnic acid-amine derivatives has been determined against a wide variety of murine and human cancer cell lines [4]. Although the cytotoxicity of usnic acid has been extensively reviewed, no data regarding the effects of usnic acid on glioblastoma cells (formally glioblastoma multiform, GBM) exists. GBM represents both the most common and most malignant variant among a number of primary brain tumors. In this study, usnic acid and ten derivatives of (+)-usnic acid were evaluated on a human glioblastoma - astrocytoma cell line (U87MG) by a MTT assay for cell viability. The N-heterocyclic

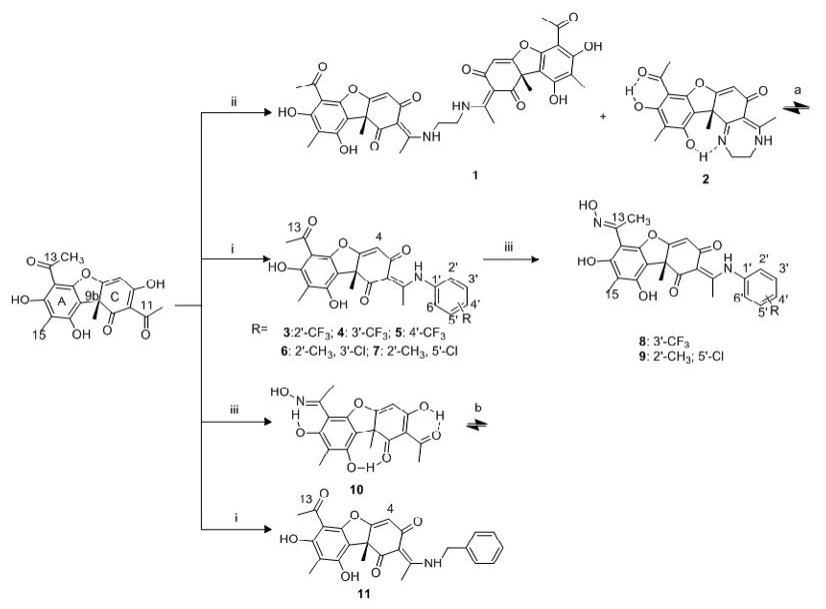

Scheme 1: Synthesis of (+)-usnic acid derivatives 1-10. Reagents and conditions: (i) $\mathrm{RNH}_{2} 1.2$ equiv., refluxing $\mathrm{EtOH}, 4 \mathrm{hrs}$; (ii) ethylene diamine 1.2 equiv., refluxing EtOH/THF 5:1, 4 hrs.; (iii) hydroxylamine 1.2 equiv. in 5\% methanolic potassium hydroxide-water $(2: 1), 50^{\circ} \mathrm{C}, \mathrm{N}_{2}, 2 \mathrm{hrs}$.; (a) The compound is tautomeric, (b) The compound is tautomeric [24]. derivative (1,4-diazepine) showed higher cytotoxicity on this cancer cell line than temozolomide (TMZ), which is the drug currently used against this cancer form.

The reaction between usnic acid and primary amines has been studied in a number of papers [10-21] leading to enamines and Schiff bases. One inherent problem with biological testing of usnic acid and some of its derivatives is a very low solubility in water [22]. The aim of this study is to synthesize new (+)-usnic acid derivatives with potential biological activities and better solubility. Ten derivatives of (+)-usnic acid were synthesized with ethylene diamine, series of aromatic amines and hydroxylamine.

\section{Experimental}

(+)-usnic acid was obtained from Sigma (USA). Ethylene diamine, 2-aminobenzotrifluoride, 3-aminobenzotrifluoride, 4-aminobenzotrifluoride, 3-chloro-2-methylaniline, 5-chloro-2methylaniline, hydroxylamine hydrochloride, benzylamine. Solvents and other reactants of high quality were purchased from Merck (Germany) and JT Baker (USA).

Melting points were measured on a Mettler Toledo (Switzerland) melting apparatus. IR spectra in $\mathrm{KBr}$ discs were recorded on a Nicolet 760 (USA) instrument. Preparative chromatography was performed on a Shimadzu LC-20AP preparative system (Japan) with Agilent Prep SIL column $(250 \times 21.2 \mathrm{~mm} ; 10 \mu \mathrm{m})$. High resolution mass (HRMS) measurements were recorded on a LCMS-IT-TOF Shimadzu (Japan) with an electrospray ion source (ESI). ${ }^{1} \mathrm{H}$ NMR and ${ }^{13} \mathrm{C}$ NMR spectra were measured at 500 and $125 \mathrm{MHz}$, respectively, on a Bruker AC-500 $\mathrm{MHz}$ (USA) or at 600 and $125 \mathrm{MHz}$ on a Varian Inova instrument in DMSO- $\mathrm{d}_{6}$ or $\mathrm{CDCl}_{3}$ using TMS as reference. 2D NMR spectra, HSQC and $\mathrm{HMBC}$ were recorded according to standard protocols.

*Corresponding author: Poul Erik Hansen, Department of Science and Environment, Roskilde University, DK-4000 Roskilde, Denmark, Tel: 004546742432; E-mail: poulerik@ruc.dk

Received March 26, 2016; Accepted April 11, 2016; Published April 18, 2016

Citation: Nguyen HGT, Nguyen NV, Vo VA, Chun W, Kamounah FS, et al. (2016) Synthesis, Structure Elucidation and Cytotoxicity of (+)-Usnic Acid Derivatives on U87MG Glioblastoma Cells. Nat Prod Chem Res 4: 216. doi:10.4172/23296836.1000216

Copyright: (c) 2016 Nguyen HGT, et al. This is an open-access article distributed under the terms of the Creative Commons Attribution License, which permits unrestricted use, distribution, and reproduction in any medium, provided the original author and source are credited. 


\section{General methods}

Procedure (A) for the preparation of compounds (1-2): A suspension of $(+)$-usnic acid $(1 \mathrm{mmol})$ in a mixture of tetrahydrofuran and absolute ethyl alcohol $(1: 5 ; 12 \mathrm{ml})$ was treated with ethylene diamine (1.2 mmol, pure liquid), and heated to reflux for $4 \mathrm{hrs}$. with stirring. After the end of the reaction, the mixture was concentrated under reduced pressure. The obtained residue was purified by preparative chromatography.

$(S, E)-6-$ acetyl-2-(1- $((2-(((E)-1-((R)-6-$ acetyl-7,9-dihydroxy8,9b-dimethyl-1,3-dioxo-3,9b-dihydrodibenzo[b,d]furan-2(1H)ylidene)ethyl)amino)ethyl)amino)ethylidene)-7,9-dihydroxy-8,9bdimethyldibenzo[b,d]furan-1,3(2H,9bH)-dione(1): While solid (163 $\mathrm{mg}, 46 \%) ; \mathrm{mp} .186-187^{\circ} \mathrm{C} ; \mathrm{R}_{\mathrm{f}}=0.51\left(\mathrm{CH}_{2} \mathrm{Cl}_{2} / \mathrm{MeOH} / \mathrm{NH}_{4} \mathrm{OH}, 95: 5: 1\right)$; IR $v\left(\mathrm{~cm}^{-1}\right) 3270,3086,2986,1696,1635,1545$; ESI-HRMS $(\mathrm{m} / \mathrm{z})$ calcd. for $\mathrm{C}_{38} \mathrm{H}_{36} \mathrm{~N}_{2} \mathrm{O}_{12}(\mathrm{M}+\mathrm{H})^{+}$713.2341, found 713.2343. ${ }^{1} \mathrm{H} \mathrm{NMR}(500 \mathrm{MHz}$, $\left.\mathrm{DMSO}_{-} \mathrm{d}_{6}\right) \delta(\mathrm{ppm}) \mathrm{J}(\mathrm{Hz}) 1.65\left(\mathrm{~s}, 3 \mathrm{H}, \mathrm{CH}_{3}-10\right) ; 1.94\left(\mathrm{~s}, 3 \mathrm{H}, \mathrm{CH}_{3}-15\right)$; $2.51\left(\mathrm{~s}, 3 \mathrm{H}, \mathrm{CH}_{3}-14\right) ; 2.62$ (s, 3H, $\left.\mathrm{CH}_{3}-12\right) ; 3.95\left(2 \mathrm{H}, \mathrm{CH}_{2}-16\right) ; 5.87$ (s, $1 \mathrm{H}, \mathrm{H}-4) ; 12.13$ (s, 1H, OH-9); 13.06 (s, 1H, NH); 13.37 (s, 1H, OH-7). ${ }^{13} \mathrm{C}$ NMR (125 MHz, DMSO-d $) \delta(\mathrm{ppm}) 7.4\left(\mathrm{CH}_{3}-15\right) ; 18.1\left(\mathrm{CH}_{3}-12\right)$; $30.9\left(\mathrm{CH}_{3}-14\right) ; 31.6\left(\mathrm{CH}_{3}-10\right) ; 42.4\left(\mathrm{CH}_{2}-16\right) ; 56.3(\mathrm{C}-9 \mathrm{~b}) ; 100.8(\mathrm{C}-6)$; 102.0 (C-2); 102.3 (C-4); 105.0 (C-9a); 106.3 (C-8); 155.7 (C-5a); 157.6 (C-9); 162.5 (C-7); 173.0 (C-4a); 175.7 (C-11); 188.7 (C-3); 197.4 (C-1); 200.8 (C-13).

(S)-9-acetyl-10,12-dihydroxy-5,11,12b-trimethyl-3,4-dihydro2H-benzo[2,3]benzofuro[4,5-e][1,4]diazepin-6(12bH)-one

Yellow solid (114 mg, 33\%); mp 176-176.5 ${ }^{\circ} \mathrm{C} ; \mathrm{R}_{\mathrm{f}}=0.25\left(\mathrm{CH}_{2} \mathrm{Cl}_{2} / \mathrm{MeOH} /\right.$ $\left.\mathrm{NH}_{4} \mathrm{OH}, 95: 5: 1\right)$; IR $v\left(\mathrm{~cm}^{-1}\right) 3450,2940,1699,1628,1551$; ESI-HRMS $(\mathrm{m} / \mathrm{z})$ calcd. for $\mathrm{C}_{20} \mathrm{H}_{20} \mathrm{~N}_{2} \mathrm{O}_{5}(\mathrm{M}+\mathrm{H})^{+} 369.1450$, found 369.1450 . For ${ }^{1} \mathrm{H}$ and ${ }^{13} \mathrm{C}$ NMR data see Table 2 .

Procedure (B) for the preparation of ketamines 3-7 and (11): A suspension of $(+)$-usnic acid $(1 \mathrm{mmol})$ in absolute ethyl alcohol $(10 \mathrm{~mL})$ was treated with amines $(1.2 \mathrm{mmol}$, neat $)$ and heated to reflux for $4 \mathrm{hr}$ with stirring. After the end of reaction, the mixture was concentrated under reduced pressure. The obtained residue was purified by preparative chromatography.

(E)-6-acetyl-7,9-dihydroxy-8,9b-dimethyl-2-(1-(2(trifluoromethyl)phenylamino)ethylidene)dibenzo[b,d]furan 1,3(2H,9bH)-dione (3): White crystals (204 mg, 42\%); m.p. $150-151^{\circ} \mathrm{C}$; $\mathrm{R}_{\mathrm{f}}=0.36$ (ethyl acetate/hexane/MeOH, 3:7:0.1); IR $v\left(\mathrm{~cm}^{-1}\right)$ 3476, 2971, 1693, 1635, 1548; ESI-HRMS (m/z) calcd. for $\mathrm{C}_{25} \mathrm{H}_{20} \mathrm{~F}_{3} \mathrm{NO}_{6}(\mathrm{M}+\mathrm{H})^{+}$ 488.1321, found 488.1325. ${ }^{1} \mathrm{H}$ NMR $\left(500 \mathrm{MHz}, \mathrm{DMSO}-\mathrm{d}_{6}\right) \delta(\mathrm{ppm}) J$ (Hz) 1.76 (s, 3H, $\left.\mathrm{CH}_{3}-10\right) ; 2.03$ (s, 3H, $\left.\mathrm{CH}_{3}-15\right) ; 2.48$ (s, 3H, $\left.\mathrm{CH}_{3}-14\right)$; 2.69 (s, 3H, $\left.\mathrm{CH}_{3}-12\right) ; 6.02(\mathrm{~s}, 1 \mathrm{H}, \mathrm{H}-4) ; 7.71\left(\mathrm{~m}, 2 \mathrm{H}, \mathrm{H}-4^{\prime}, 6\right.$ '); $7.86(\mathrm{t}$, $1 \mathrm{H}, J=7.5, \mathrm{H}-5^{\prime}$ ); 7.93 (d, 1H, J=7.5, H-3'); 11.92 (s, 1H, OH-9); 13.40 (s, $1 \mathrm{H}, \mathrm{OH}-7) ; 14.84$ (s, $1 \mathrm{H}, \mathrm{NH}) .{ }^{13} \mathrm{C} \mathrm{NMR}\left(125 \mathrm{MHz}, \mathrm{CDCl}_{3}\right) \delta(\mathrm{ppm})$ $J(\mathrm{~Hz}) 7.5\left(\mathrm{CH}_{3}-15\right) ; 20.8\left(\mathrm{CH}_{3}-12\right) ; 31.3\left(\mathrm{CH}_{3}-14\right) ; 31.9\left(\mathrm{CH}_{3}-10\right) ; 57.7$ (C-9b); 101.4 (C-6); 102.2 (C-2); 103.0 (C-4); 104.8 (C-9a); 108.3 (C-8); $122.9\left(\mathrm{CF}_{3}, J=271.5\right) ; 127.0\left(\mathrm{C}-2{ }^{\prime}, J=30.8\right) ; 127.25$ (C-3', $\left.J=5.0\right) ; 128.8$ (C-6'); 128.9 (C-4'); 133.1 (C-5'); $134.5\left(\mathrm{C}-1 '^{\prime}\right) ; 155.8$ (C-5a); 158.1 (C9); 163.6 (C-7); 173.5 (C-4a); 175.1 (C-11), 191.2 (C-3); 199.0 (C-1); 200.7 (C-13).

(E)-6-acetyl-7,9-dihydroxy-8,9b-dimethyl-2-(1-(3(trifluoromethyl)phenylamino)ethylidene)dibenzo[b,d]furan-1,3 (2H,9bH)-dion (4): White crystals $(326 \mathrm{mg}, 67 \%)$; mp. $160-160.5^{\circ} \mathrm{C}$; $\mathrm{R}_{\mathrm{f}}=0.43$ (ethyl acetate/hexane/MeOH, 3:7:0.1); IR $v\left(\mathrm{~cm}^{-1}\right)$ 3471, 3086, 2925, 1698, 1628, 1549; ESI-HRMS (m/z) calcd. for $\mathrm{C}_{25} \mathrm{H}_{20} \mathrm{~F}_{3} \mathrm{NO}_{6}$ $(\mathrm{M}+\mathrm{H})^{+}$488.1321, found 488.1323. ${ }^{1} \mathrm{H}$ NMR $\left(500 \mathrm{MHz}, \mathrm{DMSO}-\mathrm{d}_{6}\right) \delta$ (ppm) $J(\mathrm{~Hz}) 1.71\left(\mathrm{~s}, 3 \mathrm{H}, \mathrm{CH}_{3}-10\right) ; 1.98\left(\mathrm{~s}, 3 \mathrm{H}, \mathrm{CH}_{3}-15\right) ; 2.53(\mathrm{~s}, 3 \mathrm{H}$,
$\left.\mathrm{CH}_{3}-14\right) ; 2.65$ (s, 3H, $\left.\mathrm{CH}_{3}-12\right) ; 6.01\left(\mathrm{~s}, 1 \mathrm{H}, \mathrm{C}_{4}-\mathrm{H}\right) ; 7.75$ (s, 1H, H-2'); $7.80\left(\mathrm{~d}, 2 \mathrm{H}, J=5.5, \mathrm{H}-4^{\prime}, 6^{\prime}\right) ; 7.86\left(\mathrm{t}, 1 \mathrm{H}, J=5.5, \mathrm{H}-5^{\prime}\right) ; 11.92(\mathrm{~s}, 1 \mathrm{H}$, OH-9); 13.40 (s, 1H, OH-7); 14.84 (s, 1H, NH). ${ }^{13} \mathrm{C}$ NMR $(125 \mathrm{MHz}$, $\left.\mathrm{CDCl}_{3}\right) \delta(\mathrm{ppm}) J(\mathrm{~Hz}) 7.5\left(\mathrm{CH}_{3}-15\right) ; 20.6\left(\mathrm{CH}_{3}-12\right) ; 31.3\left(\mathrm{CH}_{3}-14\right)$; 31.9 ( $\left.\mathrm{CH}_{3}-10\right) ; 57.7$ (C-9b); $101.4(\mathrm{C}-6) ; 102.2$ (C-2); 103.0 (C-4); 104.8 (C-9a); 108.4 (C-8); 122.9 (C-2', J=3.8); $123.3\left(\mathrm{CF}_{3}, J=272.3\right) ; 125.0$ (C4', J=3.3); 129.2 (C-6'); 130.4 (C-5'); 132.4 (C-3', J=32.9); 136.8 (C-1'); 155.7 (C-5a); 158.1 (C-9); 163.7 (C-7); 173.9 (C-4a); 175.1 (C-11), 191.2 (C-3); 199.0 (C-1); 200.6 (C-13).

(E)-6-acetyl-7,9-dihydroxy-8,9b-dimethyl-2-(1-(4(trifluoromethyl)phenylamino)ethylidene)dibenzo[b,d]furan1,3(2H,9bH)-dione (5): White crystals (317 mg, 65\%); mp. 171$171.5^{\circ} \mathrm{C} ; \mathrm{R}_{\mathrm{f}}=0.48$ (ethyl acetate/hexane/MeOH, 3:7:0.1); IR $v\left(\mathrm{~cm}^{-1}\right)$ $3477,2925,1699,1635,1545$; ESI-HRMS (m/z) calcd. for $\mathrm{C}_{25} \mathrm{H}_{20} \mathrm{~F}_{3} \mathrm{NO}$ $(\mathrm{M}+\mathrm{H})^{+}$488.1321, found 488.1320. ${ }^{1} \mathrm{H}$ NMR $\left(500 \mathrm{MHz}, \mathrm{DMSO}-\mathrm{d}_{6}\right) \delta$ (ppm) $J(\mathrm{~Hz}) 1.72$ (s, 3H, $\left.\mathrm{CH}_{3}-10\right) ; 1.99$ (s, 3H, $\left.\mathrm{CH}_{3}-15\right) ; 2.56$ (s, $3 \mathrm{H}$, $\left.\mathrm{CH}_{3}-14\right) ; 2.66$ (s, 3H, $\left.\mathrm{CH}_{3}-12\right) ; 6.03$ (s, $\left.1 \mathrm{H}, \mathrm{H}-4\right) ; 7.65$ (d, $2 \mathrm{H}, J=7, \mathrm{H}-2$ ', 6); 7,89 (d, 2H, J=7, H-3', 5'); 11.89 (s, 1H, OH-9); 13.40 (s, 1H, OH7); $14.94(\mathrm{~s}, 1 \mathrm{H}, \mathrm{NH}){ }^{13} \mathrm{C}$ NMR $\left(125 \mathrm{MHz}, \mathrm{CDCl}_{3}\right) \delta(\mathrm{ppm}) J(\mathrm{~Hz}) 7.7$ $\left(\mathrm{CH}_{3}-15\right) ; 20.9\left(\mathrm{CH}_{3}-12\right) ; 31.5\left(\mathrm{CH}_{3}-14\right) ; 32.1\left(\mathrm{CH}_{3}-10\right) ; 57.9$ (C-9b); 101.7 (C-6); 102.4 (C-2); 103.3 (C-4); 105.0 (C-9a); 108.6 (C-8); 123.8 $\left(\mathrm{CF}_{3}-\mathrm{C}^{\prime}, \mathrm{\prime}, J=271.8\right) ; 126.4\left(\mathrm{C}-2^{\prime}, 6^{\prime}\right) ; 127.2\left(\mathrm{C}^{\prime} 3^{\prime}, 5^{\prime}, J=3.8\right) ; 130.5$ (C-4', $J=32.9$ ); 139.5 (C-1'); 155.9 (C-5a); 158.3 (C-9); 163.9 (C-7); 173.9 (C4a); 175.4 (C-11), 191.4 (C-3); 199.2 (C-1); 200.8 (C-13).

(E)-6-acetyl-2-(1-(3-chloro-2-methylphenylamino)ethylidene)7,9-dihydroxy-8,9b-dimethyldibenzo[b,d]furan-1,3(2H,9bH)-dione (6): Bright white needles ( $380 \mathrm{mg}, 78 \%) ; \mathrm{mp} .172-172.5^{\circ} \mathrm{C} ; \mathrm{R}_{\mathrm{f}}=0.47$ (ethyl acetate/hexane/MeOH, 3:7:0.1); IR $v\left(\mathrm{~cm}^{-1}\right) 3483,2923,1699$, 1635, 1542; ESI-HRMS (m/z) calcd. for $\mathrm{C}_{25} \mathrm{H}_{22} \mathrm{ClNO}_{6}(\mathrm{M}+\mathrm{H})^{+} 468.1213$, found 468.1218. ${ }^{1} \mathrm{H}$ NMR (500 MHz, DMSO-d $) \delta(\mathrm{ppm}) J(\mathrm{~Hz}) 1.73$ (s, 3H, $\left.\mathrm{CH}_{3}-10\right) ; 1.99$ (d, 3H, $\left.\mathrm{CH}_{3}-15\right) ; 2.27$ (s, 3H, $\mathrm{CH}_{3}-\mathrm{C}^{\prime}$ ); 2.45 (s, $\left.3 \mathrm{H}, \mathrm{CH}_{3}-14\right) ; 2.66$ (s, $\left.3 \mathrm{H}, \mathrm{CH}_{3}-12\right) ; 6.01(\mathrm{~s}, 1 \mathrm{H}, \mathrm{H}-4) ; 7.38$ (t, $2 \mathrm{H}, J=5$, $\left.\mathrm{H}-4^{\prime}, 6^{\prime}\right) ; 7.55$ (t, 1H, J=5, H-5'); 11.98 (s, 1H, OH-9); 13.40 (s, 1H, OH7); $14.69(\mathrm{~s}, 1 \mathrm{H}, \mathrm{NH}) .{ }^{13} \mathrm{C}$ NMR $\left(125 \mathrm{MHz}, \mathrm{DMSO}-\mathrm{d}_{6}\right) \delta(\mathrm{ppm}) 7.5$ $\left(\mathrm{CH}_{3}-15\right) ; 15.0\left(\mathrm{CH}_{3}-\mathrm{C}^{\prime}\right) ; 20.3\left(\mathrm{CH}_{3}-12\right) ; 31.0\left(\mathrm{CH}_{3}-14\right) ; 31.6\left(\mathrm{CH}_{3}\right.$ 10); 56.7 (C-9b); 100.9 (C-6); 102.2 (C-2); 102.4 (C-4); 105.0 (C-9a); 106.5 (C-8); 125.8 (C-6'); 127.7 (C-5'); 129.1 (C-4'); 132.1 (C-2'); 134.5 (C-3'); 136.4 (C-1'); 155.6 (C-5a); 157.4 (C-9); 162.6 (C-7); 173.8 (C4a); 174.7 (C-11); 189.6 (C-3); 198.1 (C-1); 200.9 (C-13).

(E)-6-acetyl-2-(1-(5-chloro-2-methylphenylamino)ethylidene)7,9-dihydroxy-8,9b-dimethyldibenzo[b,d]furan-1,3(2H,9bH)-dione (7): Bright white needles (420 mg, 86\%); mp. $234-234.5^{\circ} \mathrm{C} ; \mathrm{R}_{\mathrm{f}}=0.46$ (ethyl acetate/hexane/MeOH, 3:7:0.1); IR $v\left(\mathrm{~cm}^{-1}\right) 3447,2979,1698$, 1629, 1553; ESI-HRMS (m/z) calcd. for $\mathrm{C}_{25} \mathrm{H}_{22} \mathrm{ClNO}_{6}(\mathrm{M}+\mathrm{H})^{+} 468.1213$, found 468.1216. ${ }^{1} \mathrm{H}$ NMR (500 MHz, DMSO-d $) \delta^{6}(\mathrm{ppm}) J(\mathrm{~Hz}) 1.74$ (s, 3H, $\left.\mathrm{CH}_{3}-10\right) ; 2.00$ (d, 3H, $\left.\mathrm{CH}_{3}-15\right) ; 2.22$ (s, 3H, $\left.\mathrm{CH}_{3}-\mathrm{C}^{\prime}\right) ; 2.47$ (s, $\left.3 \mathrm{H}, \mathrm{CH}_{3}-14\right) ; 2.68\left(\mathrm{~s}, 3 \mathrm{H}, \mathrm{CH}_{3}-12\right) ; 6.03$ (s, $\left.1 \mathrm{H}, \mathrm{H}-4\right) ; 7.44$ (d, $2 \mathrm{H}, J=8.5$, H-3', 4'); 7.55 (s, 1H, H-6'); 12.01 (s, 1H, OH-9); 13.41 (s, 1H, OH-7); $14.65(\mathrm{~s}, 1 \mathrm{H}, \mathrm{NH}) .{ }^{13} \mathrm{C}$ NMR $\left(125 \mathrm{MHz}, \mathrm{DMSO}-\mathrm{d}_{6}\right) \delta(\mathrm{ppm}) 7.5\left(\mathrm{CH}_{3}-\right.$ 15); $16.9\left(\mathrm{CH}_{3}-\mathrm{C}^{\prime}\right) ; 20.2\left(\mathrm{CH}_{3}-12\right) ; 31.0\left(\mathrm{CH}_{3}-14\right) ; 31.6\left(\mathrm{CH}_{3}-10\right) ; 56.7$ (C-9b); 101.0 (C-6); 102.2 (C-2); 102.4 (C-4); 105.0 (C-9a); 106.5 (C-8); 126.4 (C-6'); 128.3 (C-4'); 130.8 (C-3'); 132.5 (C-5'); 132.8 (C-2'); 136.2 (C-1'); 155.7 (C-5a); 157.5 (C-9); 162.5 (C-7); 173.8 (C-4a); 174.7 (C11); 189.6 (C-3); 198.1 (C-1); 201.0 (C-13).

Procedure $(C)$ for the preparation of compounds (8-10): A solution of $(+)$-usnic acid or amine derivatives $(0.25 \mathrm{mmol})$ and hydroxylamine hydrochloride $(0.30 \mathrm{mmol})$ in $5 \%$ methanolic potassium hydroxide $(6 \mathrm{~mL})$ and distilled water $(3 \mathrm{~mL})$ was heated at $50^{\circ} \mathrm{C}$ under a nitrogen atmosphere for $2 \mathrm{hrs}$. The resulting solution was diluted with water $(15 \mathrm{~mL})$, acidified with $1 \mathrm{~N}$ hydrochloric acid and extracted with ethyl acetate $(3 \times 15 \mathrm{~mL})$. The combined extracts 
were concentrated under reduced pressure. The obtained residue was purified by preparative chromatography.

(E)-7,9-dihydroxy-6-((Z)-1-(hydroxyimino)ethyl)-8,9bdimethyl-2-(1-(3(trifluoromethyl)phenylamino )ethylidene) dibenzo[b,d]furan-1,3(2H,9bH)-dione (8): White solid (67 $\mathrm{mg}$, 67\%); mp. $152-153^{\circ} \mathrm{C} ; \mathrm{R}_{\mathrm{f}}=0.35$ (ethyl acetate/hexane $/ \mathrm{MeOH}, 3: 7: 0.1$ ); IR $v\left(\mathrm{~cm}^{-1}\right) 3379,2926,1692,1630,1546$; ESI-HRMS $(\mathrm{m} / \mathrm{z}) \mathrm{calcd}$. for $\mathrm{C}_{25} \mathrm{H}_{21} \mathrm{~F}_{3} \mathrm{~N}_{2} \mathrm{O}_{6}(\mathrm{M}+\mathrm{H})^{+}$503.1424, found 503.1425. ${ }^{1} \mathrm{H}$ NMR $(500 \mathrm{MHz}$, $\left.\mathrm{CDCl}_{3}\right) \delta(\mathrm{ppm}) J(\mathrm{~Hz}) 1.68\left(\mathrm{~s}, 3 \mathrm{H}, \mathrm{CH}_{3}-10\right) ; 2.00\left(\mathrm{~s}, 3 \mathrm{H}, \mathrm{CH}_{3}-15\right) ; 2.35$ (s, 3H, $\left.\mathrm{CH}_{3}-14\right) ; 2.53$ (s, 3H, $\left.\mathrm{CH}_{3}-12\right) ; 5.89(\mathrm{~s}, 1 \mathrm{H}, \mathrm{H}-4) ; 7.75(\mathrm{~s}, 1 \mathrm{H}$, H-2'); 7.79 (d, 2H, J=5.5, H-4', 6'); 7.85 (t, 1H, J=5.5, H-5'); 11.18 (s, $1 \mathrm{H}, \mathrm{OH}-9) ; 11.50$ (s, 1H, N-OH-13); 12.11 (s, 1H, OH-7); 14.91 (s, $1 \mathrm{H}$, $\mathrm{NH}) .{ }^{13} \mathrm{C}$ NMR $\left(125 \mathrm{MHz}, \mathrm{CDCl}_{3}\right) \delta(\mathrm{ppm}) J(\mathrm{~Hz}) 8.3\left(\mathrm{CH}_{3}-15\right) ; 20.3$ $\left(\mathrm{CH}_{3}-12\right) ; 31.0\left(\mathrm{CH}_{3}-14\right) ; 31.6\left(\mathrm{CH}_{3}-10\right) ; 57.0(\mathrm{C}-9 \mathrm{~b}) ; 101.3$ (C-9a); 102.7 (C-6); 104.0 (C-2); 104.3 (C-4); 106.8 (C-8); 122.9 (C-2', J=3.2); $123.6\left(\mathrm{CF}_{3}-\mathrm{C}^{\prime}, J=271.2\right) ; 124.6\left(\mathrm{C}-4^{\prime}, J=3.5\right) ; 129.6\left(\mathrm{C}^{\prime} 6^{\prime}\right) ; 130.7\left(\mathrm{C}-5^{\prime}\right)$; 132.4 (C-3', J=32.9); 136.8 (C-1'); 152.1 (C-13); 152.7 (C-7); 155.0 (C5a); 157.4 (C-9); 174.0 (C-4a); 174.4 (C-11), 189.8 (C-3); 198.7 (C-1).

(E)-2-(1-(5-chloro-2-methylphenylamino)ethylidene)7,9-dihydroxy-6-((Z)-1-(hydroxyimino)ethyl)-8,9b-dimethyl dibenzo[b,d]furan-1,3(2H,9bH)-dione (9): White needles $(87.9 \mathrm{mg}$, $70 \%$ ); $\mathrm{mp} .172-173^{\circ} \mathrm{C} ; \mathrm{R}_{\mathrm{f}}=0.37$ (ethyl acetate/hexane/ $\mathrm{MeOH}, 3: 7: 0.1$ ); IR $v\left(\mathrm{~cm}^{-1}\right) 3414,2921,1698,1630,1538$; ESI-HRMS (m/z) calcd. for $\mathrm{C}_{25} \mathrm{H}_{23} \mathrm{ClN}_{2} \mathrm{O}_{6}(\mathrm{M}+\mathrm{H})^{+}$483.1323, found $483.1326 .{ }^{1} \mathrm{H}$ NMR $(500 \mathrm{MHz}$, DMSO-d $\left.\mathrm{d}_{6}\right) \delta(\mathrm{ppm}) J(\mathrm{~Hz}) 1.78\left(\mathrm{~s}, 3 \mathrm{H}, \mathrm{CH}_{3}-10\right) ; 2.00\left(\mathrm{~s}, 3 \mathrm{H}, \mathrm{CH}_{3}-15\right)$; 2.20 (s, 3H, $\mathrm{CH}_{3}-\mathrm{C}^{\prime}$ ); 2.45 (s, 3H, $\left.\mathrm{CH}_{3}-14\right) ; 2.66$ (s, 3H, $\left.\mathrm{CH}_{3}-12\right) ; 6.00$ (s, 1H, H-4); 7.43 (d, 2H, J=8, H-3', '4); 7.53 (s, 1H, H-6'); 11.49 (s, 1H, N-OH-13); 12.09 (s, 1H, OH-9); 13.40 (s, 1H, OH-7); 14.65 (s, 1H, NH). ${ }^{13} \mathrm{C}$ NMR (125 MHz, DMSO-d $) \delta(\mathrm{ppm}) 7.5\left(\mathrm{CH}_{3}-15\right) ; 16.9\left(\mathrm{CH}_{3}-\mathrm{C}^{\prime}\right)$; $20.1\left(\mathrm{CH}_{3}-12\right) ; 31.0\left(\mathrm{CH}_{3}-14\right) ; 31.7\left(\mathrm{CH}_{3}-10\right) ; 56.9$ (C-9b); $101.3(\mathrm{C}-6)$; 102.2 (C-2); 102.5 (C-4); 104.4 (C-9a); 106.7 (C-8); 126.4 (C-6); 128.2 (C-4'); 130.8 (C-3'); 132.4 (C-5'); 132.8 (C-2'); 136.3 (C-1'); 155.0 (C5a); 155.7 (C-13); 157.3 (C-9); 162.6 (C-7); 173.8 (C-4a); 174.5 (C-11); 189.8 (C-3); 198.5 (C-1).

(9bR)-2-acetyl-7,9-dihydroxy-6-((E)-1-(hydroxyimino)ethyl)8,9b-dimethyldibenzo[b,d]furan-1,3(2H,9bH)-dione (10): Yellow solid (94.6 mg, 72\%); mp. $191-192^{\circ} \mathrm{C} ; \mathrm{R}_{\mathrm{f}}=0.47$ (ethyl acetate/hexane/ $\mathrm{MeOH}, 3: 7: 0.1)$; IR $v\left(\mathrm{~cm}^{-1}\right) 3399,3088,2929,1696,1625,1575$; ESIHRMS $(\mathrm{m} / \mathrm{z})$ calcd. for $\mathrm{C}_{18} \mathrm{H}_{17} \mathrm{NO}_{7}(\mathrm{M}+\mathrm{H})^{+} 360.1083$, found 360.1084 . ${ }^{1} \mathrm{H}$ NMR $\left(500 \mathrm{MHz}, \mathrm{CDCl}_{3}\right) \delta(\mathrm{ppm}) J(\mathrm{~Hz}) 1.74\left(\mathrm{~s}, 3 \mathrm{H}, \mathrm{CH}_{3}-10\right) ; 2.13$ (s, $\left.3 \mathrm{H}, \mathrm{CH}_{3}-15\right) ; 2.46$ (s, 3H, $\left.\mathrm{CH}_{3}-14\right) ; 2.67$ (s, $\left.3 \mathrm{H}, \mathrm{CH}_{3}-12\right) ; 5.90$ (s, $1 \mathrm{H}, \mathrm{H}-4) ; 10.55$ (s, 1H, N-OH-13); 11,73 (s, 1H, OH-9); 13.31 (s, 1H, $\mathrm{OH}-7) ; 18,77$ (s, $1 \mathrm{H}, \mathrm{OH}-3) .{ }^{13} \mathrm{C}$ NMR $\left(125 \mathrm{MHz}, \mathrm{CDCl}_{3}\right) \delta$ (ppm) 8.2 $\left(\mathrm{CH}_{3}-15\right) ; 14.0\left(\mathrm{CH}_{3}-14\right) ; 27.9\left(\mathrm{CH}_{3}-12\right) ; 32.2\left(\mathrm{CH}_{3}-10\right) ; 59.2(\mathrm{C}-9 \mathrm{~b})$; 97.4 (C-4); 98.9 (C-6); 104.0 (C-9a); $105.3(\mathrm{C}-2) ; 109.3$ (C-8); 153.1 (C5a); 157.8 (C-13); 158.0 (C-7); 180.2 (C-4a); 191.7 (C-3); 198.3 (C-1); 201.6 (C-11).

\section{Preparative chromatography}

High-speed fractionation was performed using a column with a high separation capacity so the obtained compounds could be achieved with high purity. The obtained residue was purified on a Shimadzu LC-20A using a silica column at ambient temperature. Separation was achieved using the mobile phases in Table 3 at a flow rate of $12 \mathrm{ml} / \mathrm{min}$ and was monitored using a PDA detector at $254 \mathrm{~nm}$. In the purification step the yields were finally obtained in the range from $33 \%$ to $72 \%$.

\section{Biological studies}

Cell culture and drug treatment: The biological studies were conducted in department of Pharmacology, School of Medicine, Kangwon National University, Chuncheon, Korea.

Human cancer cell line: U87MG glioblastoma cells were obtained from the Korean Cell Line Bank (KCLB), cultured in Dulbecco's modified Eagle's medium (DMEM; GIBCO BRL, Grand Island, NY, USA) plus $10 \%$ fetal bovine serum (FBS; Hyclone Laboratories, Inc.), $100 \mathrm{U} / \mathrm{mL}$ of penicillin, $100 \mathrm{mg} / \mathrm{mL}$ of streptomycin (GIBCO BRL, Grand Island, NY, USA). Cells were maintained at $37^{\circ} \mathrm{C}$ under a humidified $5 \% \mathrm{CO}_{2}$ atmosphere.

Cell viability by the MTT assay: U87MG glioblastoma cells were plated into 12 -well culture plates and were incubated in $10 \%$ serum culture at $37^{\circ} \mathrm{C}$ under a $5 \% \mathrm{CO}_{2} / 95 \%$ humidified air incubator for $24 \mathrm{hrs}$. Cells were then incubated with TMZ, (+)-usnic acid or compounds 1-10 at indicated concentrations in serum free DMEM for an additional $24 \mathrm{hrs}$. The compounds were dissolved in DMSO and the level of DMSO in treatments did not exceed $0.1 \%$. Cell viability was determined using the MTT 3-(4,5-dimethylthiazol-2-yl)-2,5-diphenyl tetrazolium bromide assay, which yields a blue formazan product in living cells, but not in dead cells or their lytic debris. Then, cells were washed with PBS (phosphate buffered saline) and dissolved in DMSO (dimethyl sulfoxide, Sigma Aldrich). Absorbance was determined at 540 $\mathrm{nm}$. The results were expressed as a percentage of MTT assay activity relative to the non-treated control. $\mathrm{CC}_{50}$ 's of the specific compound was calculated, based on three concentrations using Origin software (www. originlab.com). The concentration of treating compounds at which $50 \%$ cell alive compared to non-treated samples was calculated from formula in corresponding to correlation curve formed individually, being considered as $\mathrm{CC}_{50}$ 's of each compound. The experiments were repeated three times independently.

\section{Theoretical calculations}

The molecular geometries were optimised using the Gaussian09 suite of programs [23], Density Functional Theory (DFT) (Beckes [24] exchange and Lee, Yang, Parr [25] correlation term, B3LYP and basis set $6-31 \mathrm{G}(\mathrm{d}, \mathrm{p})$ was used. The nuclear shieldings were calculated using the GIAO approach [25-27].

\section{Results and Discussion}

\section{Synthesis}

The reaction of (+)-usnic acid (2.0 equivalents) and ethylene diamine (1.0 equivalent) in a mixture of absolute ethyl alcohol and tetrahydrofuran $(5: 1)$ at reflux for $4 \mathrm{hr}$ produced compound $\mathbf{1}$ only [28]. In our hands, the reaction of (+)-usnic acid (1.0 equivalent) and ethylene diamine (1.2 equivalents) gave compound $\mathbf{1}$ and the $\mathrm{N}$-heterocyclic derivative $\mathbf{2}$ under the same conditions. The latter was predominant.

Compounds 3-5 were synthesized in absolute ethyl alcohol at reflux for $4 \mathrm{hrs}$. The reaction leading to compound 3 (42\%) showed lower yield than compounds $4\left(m-\mathrm{CF}_{3} ; 67 \%\right)$ and $\mathbf{5}\left(p-\mathrm{CF}_{3} ; 65 \%\right)$ (Scheme 1$)$.

Under similar conditions 3-chloro-2-methylaniline and 5-chloro2-methylaniline gave compounds $\mathbf{6}$ and $\mathbf{7}$ in good yields, bright crystal needles $78 \%, 86 \%$, respectively.

Treatment of compounds $\mathbf{4}, \mathbf{7}$ and (+)-usnic acid with hydroxylamine hydrochloride in $5.0 \%$ methanolic potassium hydroxide - water $(2: 1)$ at $50^{\circ} \mathrm{C}[10]$ resulted in good yields of the corresponding oximes $(\mathbf{8}, 9$ and $\mathbf{1 0})$.

\section{Structure elucidation and NMR chemical shift assignments}

As shown by Kutney and Sanchez $[11,14,15,19,20]$ does the 
reaction with primary amines occur at the carbonyl group $\mathrm{C}(11)=\mathrm{O}$ leading to an enamine. This is confirmed in this study. Schiff base formation involves the amine attacking at $\mathrm{C}+=\mathrm{O}$. $\mathrm{C}-11$ is part of a triketone system and therefore is more reactive than $\mathrm{C}$ - 13 being part of an aromatic systems. This means that the Schiff base is formed at C-11.

The assignment of the NMR chemical shifts is central to the assignment of structures. Following the assignments of Ref. [19] it can be seen that the chemical shifts of the A-ring (Scheme 1) of mono substituted derivatives are very similar to those of usnic acid itself. The assignments of the other compounds are based on chemical shifts of usnic acid and this reasoning. For the benzene rings of compounds 3-7, C-F coupling constants are of great help in derivatives 3-5 and the resonances of the benzene rings of compounds 6 and 7 can then be assigned based on substituent effects.

The structure and assignment of compound $\mathbf{2}$ will be discussed separately as the structure is rather complex. Based upon the HSQC spectrum (Table 1) C-4 can be assigned unambiguously and the methylene carbons can be identified. Based on the HMBC spectrum (Table 1) long-range correlations from $\mathrm{OH}-7$ confirm the assignment of C-6, C-7 and C-8. Knowing the assignment of C-6 the cross-peak from $\mathrm{CH}_{3}-14$ assigns $\mathrm{H}-14$ as well as $\mathrm{C}-13$. Knowing the position of C-8, cross-peaks from $\mathrm{CH}_{3}-15$ assigns $\mathrm{H}-15$. The cross-peak from $\mathrm{OH}-9$ confirms that the resonances in the HMBC spectrum overlap, although they are separate in the 1D spectrum at a lower field. H-4 helps to assign $\mathrm{C}-2$ and $\mathrm{C}-4 \mathrm{a}$. As $\mathrm{H}-10$ and $\mathrm{H}-15$ are now assigned, the remaining methyl signal must be those of $\mathrm{H}-12$ and $\mathrm{H}-14$. Crosspeaks from these assign $\mathrm{C}-13$ and $\mathrm{C}-11$. Cross-peaks from $\mathrm{H}-10$ assign $\mathrm{C}-9 \mathrm{a}, \mathrm{C}-4 \mathrm{a}$ and $\mathrm{C}-1$. The latter is very important and the assignment is confirmed by cross-peaks to the $\mathrm{CH}_{2}$ protons. The chemical shifts in DMF- $\mathrm{d}_{7}$ are very similar to those in $\mathrm{CDCl}_{3}$ (Table 1) so we may assume that the structure is similar in the two solvents.

Deuterium isotope effects on chemical shifts have also been studied in order to support the structural assignment. The deuteriation is done by dissolving the compound in $\mathrm{CH}_{3} \mathrm{OD}$ and removing the methanol by rotary evaporation. This type of isotope effect is useful in the study of intramolecularly hydrogen bonded compounds $[29,30]$. The deuterium isotope effect at C-9 $(0.6 \mathrm{ppm})$ is unusually large. Also C-11 shows large isotope effects although somewhat broad. The large effect at C-9 indicates a strong intramolecular hydrogen bond or an equilibrium system $[31,32]$. The former is in line with the large $\mathrm{OH}$ chemical shift of $15.6 \mathrm{ppm}$. Both the $\mathrm{OH}-7$ and the $\mathrm{NH}$ resonance show splittings due to isotope effects.

Based on the above information a structure can be suggested as seen in Figure 2. However, upon cooling to $-60^{\circ} \mathrm{C}$ two broad resonances appear in the ${ }^{1} \mathrm{H}$ spectrum at 12.7 and $9.95 \mathrm{ppm}$ integrating roughly 1:1. These are ascribed to $\mathrm{NH}$ resonances. Furthermore, the $\mathrm{CH}_{2}$ resonances merge to one broad resonance. In the ${ }^{13} \mathrm{C}$ spectrum many resonances are now broad: $\mathrm{C}-1, \mathrm{C}-4, \mathrm{C}-9, \mathrm{C}-10, \mathrm{C}-11$ and $\mathrm{CH}_{2} \mathrm{CH}_{2}$ indicating that an exchange situation is at hand, suggesting that two different tautomer's exist as seen in Figure 1.

A comparison between calculated and experimental data for structure A shows a very good correlation (Figure 2). This correlation is not improved by adding data for structure B, so the former must dominate at ambient temperature. Kutney and Sanchez [10] found that using hydroxylamine hydrochloride in $5.0 \%$ methanolic potassium hydroxide - water (2:1) with the dibenzyl ether of usnic acid resulted in oxime formation at carbon 13 although a more logical result would have been at $\mathrm{C}-11$ as amines react at this position (see previously). However, HMBC spectra confirmed that for $\mathbf{1 0}$ the reaction had occurred at C-13 (Scheme 1).

\section{Biological activity}

The MTT assay [29] was applied to evaluate the cytotoxicity of the derivatives on the human glioblastoma-astrocytoma cell line (U87MG) (Table 2).

The cytotoxicity of (+)-usnic acid and derivatives has been

\begin{tabular}{|c|c|c|c|c|}
\hline Carbon & ${ }^{1} \mathrm{H}^{\mathrm{a}}$ & ${ }^{13} \mathrm{C}^{\mathrm{a}}$ & Long range correlations & ${ }^{13} C^{b}$ \\
\hline 1 & & 175.9 & & 175.0 \\
\hline 2 & & 100.5 & & 99.9 \\
\hline 3 & & 187.95 & & 187.4 \\
\hline 4 & 5.74 & $103.5^{c}$ & $56.1 ; 100.5 ; 174.1$ & 103.7 \\
\hline $4 a$ & & 174.1 & & 174.1 \\
\hline $5 a$ & & 156.3 & & 157.6 \\
\hline 6 & & 100.1 & & 99.4 \\
\hline 7 & & 163.65 & & 167.3 \\
\hline 8 & & 108.1 & & 108.1 \\
\hline 9 & & 162.1 & & 164.0 \\
\hline $9 a$ & & 107.1 & & 107.7 \\
\hline $9 b$ & & 56.1 & & 56.2 \\
\hline 10 & 1.74 & $31.8^{\mathrm{c}}$ & $56.1 ; 107.1 ; 174.1 ; 175.9$ & 33.0 \\
\hline 11 & & 167.7 & & 172.6 \\
\hline 12 & 2.67 & $27.5^{\mathrm{c}}$ & 167.7 & 26.8 \\
\hline 13 & & 200.4 & & 199.8 \\
\hline 14 & 2.60 & $31.2^{\mathrm{c}}$ & $100.1 ; 200.4$ & 31.1 \\
\hline 15 & 2.03 & $7.0^{c}$ & $108.1 ; 163.65$ & 8.4 \\
\hline 16 & 3.8 and 4.2 & $50.0^{c}$ & $48.9 ; 175.9$ & 50.7 \\
\hline 17 & 3.55 and 3.8 & $48.9^{c}$ & 50.0 & 48.8 \\
\hline $\mathrm{OH}-7$ & 13.44 & & $100.1 ; 108.1 ; 163.65$ & \\
\hline $\mathrm{OH}-9$ & $15.65(\mathrm{br})$ & & $100.1(v w)^{d} ; 108.1(v w)$ & \\
\hline NH & 7.27 (br) & & & \\
\hline
\end{tabular}

${ }^{\mathrm{a} C D C l}$; ${ }^{\mathrm{b} D M F}-\mathrm{d}_{7}$; ${ }^{\mathrm{c} O b s e r v e d}$ in a HSQC spectrum; d $\mathrm{vw}$ means very weak Table 1: ${ }^{1} \mathrm{H}$ and ${ }^{13} \mathrm{C}$ chemical shifts of compound 2 .

\begin{tabular}{|c|c|c|c|}
\hline Compounds & Conc. $(\mu \mathrm{M})$ & Cell viability (\% control) 24 hrs & $\mathrm{CC}_{50}(\mu \mathrm{M})$ \\
\hline DMSO & & $101.0 \pm 10.09^{a}$ & \\
\hline (+)-Usnic acid & $\begin{array}{c}10 \\
50 \\
100\end{array}$ & $\begin{array}{c}114.0 \pm 14.3 \\
34.3 \pm 8.1 \\
20.0 \pm 7.8\end{array}$ & 46.99 \\
\hline 1 & & & $>>100$ \\
\hline 2 & $\begin{array}{c}10 \\
50 \\
100\end{array}$ & $\begin{array}{c}102.3 \pm 7.7 \\
33.6 \pm 7.0 \\
11.3 \pm 0.7\end{array}$ & 33.14 \\
\hline 3 & & & $>>200$ \\
\hline 4 & $\begin{array}{c}10 \\
100 \\
400\end{array}$ & $\begin{array}{c}102.4 \pm 1.4 \\
104.63 \pm 10.7 \\
75.71 \pm 12.0\end{array}$ & $>400$ \\
\hline 5 & & & $>>200$ \\
\hline 6 & & & $>>100$ \\
\hline 7 & & & $>>200$ \\
\hline 8 & $\begin{array}{c}10 \\
100 \\
400\end{array}$ & $\begin{array}{c}83.2 \pm 1.3 \\
29.1 \pm 6.6 \\
8.0 \pm 2.5\end{array}$ & 44.17 \\
\hline 9 & & & $>>100$ \\
\hline 10 & $\begin{array}{c}10 \\
50 \\
100\end{array}$ & $\begin{array}{l}102.7 \pm 4.7 \\
71.3 \pm 6.7 \\
48.3 \pm 0.8\end{array}$ & 94.13 \\
\hline TMZ & $\begin{array}{l}100 \\
400\end{array}$ & $\begin{array}{l}\text { 83. } 3 \pm 14.5 \\
61.0 \pm 14.1\end{array}$ & $>100$ \\
\hline
\end{tabular}

aData represent means of three independent experiments \pm SD. Compounds were tested at the highest possible concentration keeping the DMSO concentration at $0.1 \% \mathrm{v} / \mathrm{v}$.

Table 2: Cytotoxicity of (+)-usnic acid and of ten derivatives 1-10 on the U87MG cell line. 


\begin{tabular}{|c|c|}
\hline Compound & Mobile phase \\
\hline $\mathbf{1}$ & Chloroform - Methanol - Ammonia $(95: 5: 0.1)$ \\
\hline $\mathbf{2}$ & Chloroform - Methanol - Ammonia $(95: 5: 0.1)$ \\
\hline $\mathbf{3}$ & Ethyl acetate - hexane $(5: 5)$ \\
\hline $\mathbf{4}$ & Ethyl acetate - hexane $(4: 6)$ \\
\hline $\mathbf{5}$ & Ethyl acetate - hexane $(3: 7)$ \\
\hline $\mathbf{8}$ & Ethyl acetate - hexane $(4: 6)$ \\
\hline $\mathbf{9}$ & Ethyl acetate - hexane $(4: 6)$ \\
\hline $\mathbf{1 0}$ & Ethyl acetate - hexane $(4: 6)$ \\
\hline
\end{tabular}

Table 3: Mobile phases for preparative chromatography.

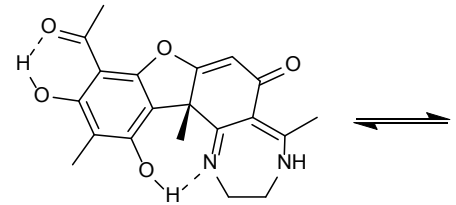

A

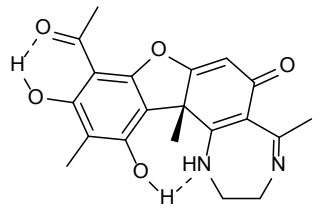

B
Figure 1: Tautomeric structures of compound 2.

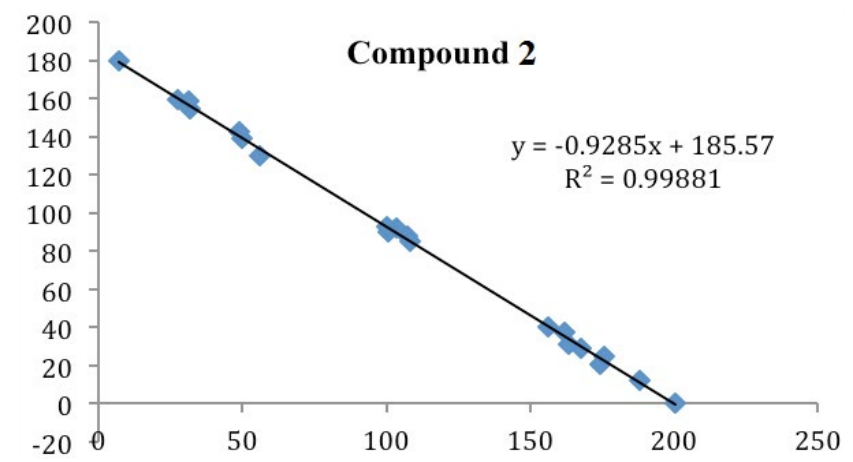

Figure 2: Plot of calculated (B3LYP-631G*) ${ }^{13} \mathrm{C}$ nuclear shielding's vs. experimental ${ }^{13} \mathrm{C}$ chemical shift.

extensively reviewed $[2,4,33,34]$, but there is no published data regarding its activity against U87MG cells, which was most commonly used to study glioblastoma multiform (GBM), the most aggressive brain cancer, according to WHO (World Health Organization). As seen in Table 2 the cytotoxicity of (+)-usnic acid and its ketamine-derivatives reduce the cell viability of U87MG significantly. Temozolomide (TMZ) is a DNA-alkylating agent approved by the U.S. Food and Drug Administration for treatment of the newly diagnosed GBM. However, the response of U87MG cell to TMZ is lower than that of (+)-usnic acid and its derivatives, whereas derivatives $2,4,8,10$ and $(+)$-usnic acid show significantly cytotoxic effects on U87MG cells after $24 \mathrm{hr}$ of treatment.

(+)-Usnic acid has a low solubility $[22,34]$ in water $(<250 \mu \mathrm{M}$, $\left.25^{\circ} \mathrm{C}\right)$, ethanol $\left(500 \mu \mathrm{M}, 25^{\circ} \mathrm{C}\right)$ and organic solvents such as ethyl acetate or methanol. In this cytotoxicity study, TMZ, (+)-usnic acid and its derivatives were dissolved in DMSO, and derivatives $\mathbf{8}$ had a better solubility in DMSO and ethanol $\left(100 \mu \mathrm{M}, 25^{\circ} \mathrm{C}\right)$ than $(+)$-usnic acid. Thus, the dose of derivative 8 can be increased to $400 \mu \mathrm{M}$ which significantly decreases the U87MG cell viability of $92 \%$ after $24 \mathrm{hr}$ of treatment. In contrast, the chloro-2-methylaniline $(6,7,9)$ derivatives have less activity on U87MG cells than the others. Compound 2 was the most potent usnic acid derivative against $U 87 \mathrm{MG}$ cells $\left(\mathrm{CC}_{50}=33.14\right.$ $\mu \mathrm{M}$ and displayed dramatically higher activity than (+)-usnic acid or TMZ (Table 2).
The sensitivity of $(+)$-usnic acid is varying from one cell line to the next. The $\mathrm{CC}_{50}$ observed in U87MG cells after $24 \mathrm{hrs} .(47 \mu \mathrm{M})$ is corresponding to previously published $\mathrm{IC}_{50}$ values in K-562 and DU145 cells (53 and $57 \mathrm{mM}$, respectively), but after $72 \mathrm{hrs}$. [4]. The time effects of (+)-usnic acid need to be addressed. In human keratinocytes (HaCaT) $\mathrm{IC}_{50}$ was estimated to $70 \mu \mathrm{M}$ for (+)-usnic acid after $24 \mathrm{hrs}$. [20]. Both the (+) and (-) isomer of usnic acid are found naturally and the (-)-isomer shows generally a lower cytotoxicity compared to $(+)$-isomers $[4,35]$. Although a recent study relating to Mycobacterium tuberculosis showed similar activity for the two isomers [35]. A recent paper by Bruno et al. showed less cytotoxicity in rat myoblasts (L6 cells) of Schiff bases of usnic acid relative to the mother compound itself [19]. Our preliminary bioactivity data suggests that (+)-usnic acid and its derivatives could be potential cancer chemical therapy agent although a profound study is needed to examine the specificity of cytotoxicity on cancer cell lines as well as mechanism of activities in vitro and in vivo.

\section{Conclusions}

Condensation of (+)-usnic acid with amines and hydroxylamine gave a series of ketamine derivatives and its oxime derivatives. Of particular interest is the formation of a new type of compound 2 . In addition, the cytotoxic activity of (+)-usnic acid and ketamine derivatives was evaluated using a MTT assay. The new compounds 2 and $\mathbf{8}$ were more active compounds in terms of cytotoxicity and they had an improved solubility. Compound 2 showed better activities $\left(\mathrm{CC}_{50}=33.14 \mu \mathrm{M}<46.99 \mu \mathrm{M}\right)$ than $(+)$-usnic acid in this study. However, further investigations are needed to evaluate the biological activity of these compounds in relation to U87MG cancer cells and to improve the activity of usnic acid derivatives in vivo.

\section{Acknowledgements}

This work was supported by a research grant from the Institute of Drug Quality Control, Ho Chi Minh City, Vietnam.

\section{References}

1. Araújo AA, De Melo MG, Rabelo TK, Nunes PS, Santos SL, et al. (2015) Review of the biological properties and toxicity of usnic acid. Nat Prod Res 29: 2167-2180.

2. Cocchietto M, Skert N, Nimis PL, Sava GA (2002) Review on usnic acid, an interesting natural compound. Naturwissenschaften 89: 137-146.

3. Campanella L, Delfini M, Ercole P, lacoangeli A, Risuleo G (2002) Molecular characterization and action of usnic acid: a drug that inhibits proliferation of mouse polyomavirus in vitro and whose main target is RNA transcription. Biochimie 84: 329-334.

4. Bazin MA, Le Lamer AC, Delcros JG, Rouaud I, Uriac P, et al. (2008) Synthesis and cytotoxic activities of usnic acid derivatives. Bioorg Med Chem 16: 68606866.

5. Backorova M, Jendzelovsky R, Kello M, Backor M, Mikeš J, et al. (2012) Lichen secondary metabolites are responsible for induction of apoptosis in HT-29 and A2780 human cancer cell lines. Toxicol in Vitro 26: 462-468.

6. Okuyama E, Umeyama K, Yamazaki M, Kinoshita Y, Yamamoto Y (1995) Usnic acid and diffractaic acid as analgesic and antipyretic components of Usnea diffracta. Planta Med 61: 113-115.

7. Cardarelli M, Serino G, Campanella L, Ercole P, De Cicco Nardone F, et al (1997) Antimitotic effects of usnic acid on different biological systems. Cell Mol Life Sci 53: 667-672.

8. Guo L, Shi Q, Fang JL, Mei N, Ali AA, et al. (2008) Review of usnic acid and Usnea barbata toxicity. J Environ Sci Health C Environ Carcinog Ecotoxicol Rev 26: 317-338.

9. Kupchan SM, Kopperman HL (1975) I-usnic acid: tumor inhibitor isolated from lichens. Experientia 31: 625.

10. Kutney JP, Leman JD, Salisbury PJ, Shanchez IH, Yee T (1977) Studies in the usnic acid series. VII. The biodegradation of (+)-usnic acid by a Pseudomonas species. Isolation, structure determination, and synthesis of (+)-6-desacetylusnic acid. Can J Chem 55: 2336-2352. 
Citation: Nguyen HGT, Nguyen NV, Vo VA, Chun W, Kamounah FS, et al. (2016) Synthesis, Structure Elucidation and Cytotoxicity of (+)-Usnic Acid Derivatives on U87MG Glioblastoma Cells. Nat Prod Chem Res 4: 216. doi:10.4172/2329-6836.1000216

11. Kutney JP, Shanchez IH (1976) Studies in the usnic acid series. I. The condensation of $(+)$-usnic acid with aliphatic and aromatic amines. Can J Chem 54: $2795-2803$

12. Kutney JP, Shanchez IH (1977) Studies in the usnic acid series. VI. The preparation of some ether derivatives of (+)-usnic acid. Can J Chem 55: 1073-1078.

13. Kutney JP, Shanchez IH, Yee T (1976) Studies in the usnic acid series. VII. The biodegradation of $(+)$-usnic acid by a Pseudomonas species. Isolation, structure determination, and synthesis of (+)-6-desacetylusnic acid. Can J Chem 54: 3713-3720.

14. Luzina OA, Polovinka MP, Salakhutdinov NF, Tolstikov GA (2007) Chemica modification of usnic acid 2. Reactions of (+)-usnic acid with amino acids. Russ Chem Bull 56: 1249-1251.

15. Luzina OA, Polovinka MP, Salakhutdinov NF, Tolstikov GA (2009) Chemical modification of usnic acid: III. Reaction of $(+)$-Usnic Acid with Substituted Phenylhydrazines. Russ J Org Chem 45: 1783-1789.

16. Mayer M, O'Neill MA, Murray KE, Santos-Magalhães NS, Carneiro-Leão AM, et al. (2005) Usnic acid: a non-genotoxic compound with anti-cancer properties. Anticancer Drugs 16: 805-809.

17. Tazetdinova AA, Luzina OA, Polovinka MP, Salakhutdinov NF, Tolstikov GA (2009) Amino-derivatives of usnic acid. Chem Nat Comp 45: 800-804.

18. Sokolov DN, Luzina OA, Salakhutdinov NF (2012) Usnic acid: preparation, structure, properties and chemical transformations. Russ Chem Rev 81: 747768.

19. Bruno M, Trucchi B, Monti D, Romeo S, Kaiser M, et al. (2013) Synthesis of a Potent antimalarial Agent through Natural Products Conjugation. ChemMedChem. 8: 221-225.

20. Bruno M, Trucchi B, Burlando B, Ranzato E, Martinotti S, et al. (2013) (+)-Usnic acid enamines with remarkable cicatrizing properties. Bioorg Med Chem 21: 1834-1843.

21. Luzina OA, Sokolov DN, Pokrovskii MAAG, Pokrovskii OB, Bekker VN, et al. (2015) Synthesis and Biological Activity of Usnic Acid Enamine Derivatives Chemistry of Natural Compounds. Chem Nat Comp 51 : 646-651.

22. Kristmundsdóttir T, Aradóttir HA, Ingólfsdóttir K, Ogmundsdóttir HM (2002) Solubilization of the lichen metabolite (+)-usnic acid for testing in tissue culture. J Pharm Pharmacol 54: 1447-1452.
23. Frisch MJ, Trucks GW, Schlegel HB, Scuseria GE, Robb MA, et al. (2009) Gaussian, Inc., Wallingford CT.

24. Becke AD (1988) Density-functional exchange-energy approximation with correct asymptotic behavior. Phys Rev A Gen Phys 38: 3098-3100.

25. Lee C, Yang W, Parr RG (1988) Development of the Colle-Salvetti correlationenergy formula into a functional of the electron density. Phys Rev B Condens Matter 37: 785-789.

26. Wolinski K, Hilton F F, Pulay P (1990) Efficient implementation of the gaugeindependent atomic orbital method for NMR chemical shift calculations. J Am Chem Soc 112: 8251-8260.

27. Ditchfield R (1974) Self-consistent perturbation theory of diamagnetism. I. A gageinvariant LCAO (linear combination of atomic orbitals) method for NMR chemical Shifts. Mol Phys 27: 789-807.

28. Krugler MC, Tomasi S, Uriac P, Toupet L, Weghe P (2008) Preparation and characterization of copper(II) and nickel(II) complexes of a new chiral salen ligand derived from (+)-usnic acid. RSC Dalton Trans 46: 6524-6526.

29. Hansen PE (1986) Deuterium Isotope Effects on 13C Nuclear Shiel 7 ding of Intra molecular Hydrogenbonded Systems. Magn Reson Chem 24: 903-910.

30. Bolvig S, Hansen PE (2000) Isotope Effects on chemical shifts as an analytical tool in structural studies of intramolecularly hydrogenbonded compounds. Curr Org Chem 4: 19-54.

31. Mosmann T (1983) Rapid colorimetric assay for cellular growth and survival: application to proliferation and cytotoxicity assays. J Immunol Methods 65: 5563.

32. O'Neill MA, Mayer M, Murray KE, Rolim-Santos HM, Santos-Magalhães NS, et al. (2010) Does usnic acid affect microtubules in human cancer cells? Braz Biol 70: 659-664.

33. Takai M, Uehara Y, Beisler JA (1979) Usnic acid derivatives as potential antineoplastic agents. Med Chem 22: 1380-1384.

34. Koparal AT, Ayaz Tüylü B, Türk H (2006) In vitro cytotoxic activities of (+)-usnic acid and (-)-usnic acid on V79, A549, and human lymphocyte cells and their non-genotoxicity on human lymphocytes. Nat Prod Res 20: 1300-1307.

35. Bekker O, Sokolov DN, Luzina OS, Komarova NI, Gatilov YV, et al. (2015) Synthesis and activity of (+)-usnic acid and (-)-usnic acid derivatives containing 1,3-thiazole cycle against Mycobacterium tuberculosis. Med Chem Res 24 2926-2938. 